\title{
Consumption as a Lifestyle: A Reflection on the Schopenhauer Perspective
}

\author{
Rafael Lucian ${ }^{1}$ \\ ${ }^{1}$ Mestrado Profissional em Gestão Empresarial, Faculdade Boa Viagem-DeVry, Brasil \\ Correspondence: Rafael Lucian, Rua Jean Émile Favre, 422, Imbiribeira 51200-060, Recife, Pernambuco, Brasil. \\ Tel: 55-81-3081-4444. E-mail: rlucian@ @bv.edu.br \\ Received: March 25, 2015 \\ Accepted: April 23, 2015 \\ Online Published: May 25, 2015 \\ doi:10.5539/ibr.v8n6p45 \\ URL: http://dx.doi.org/10.5539/ibr.v8n6p45
}

\begin{abstract}
Consuming extrapolates utilitarianism and hedonism; shopping as a purely rational activity does not complete the set of motivations that drive consumption. This theoretical essay investigates the context from the perspective of the contemporary consumer, mainly the philosophy of Schopenhauer and other authors who discuss the topic. To understand consumption, Will and Representation require one to first comprehend the theories of knowledge that elevate Science, its logic and true legitimacy and pathways that ultimately reveal the understanding of Marketing on consumer behavior. At the end of this essay, reflection leads to understanding that the metaphysics of beauty according to Schopenhauer (2012) presents pragmatic compounds still present that align marketing actions with the search for a better quality of life through aesthetics, excelling the dualistic logic of utilitarian or hedonic consumption and its recompense of mere immediate effect.
\end{abstract}

Keywords: consumer behavior, Schopenhauer, Aestetics, hedonic consumption, utility consumption

\section{Introduction}

People have needs that can be met by the purchasing of products. From basic functions such as food and clothing to complex concepts such as entertainment conform to the same theory of purchasing decisions, which varies in magnitude trying to contemplate the phenomenon of buying as a whole.

Among the major theoretical divisions of the field of consumer behavior is the understanding that a purchase can be of utilitarian or hedonic origin (Doong, Wang, \& Law, 2012), the first being that the buying decision is based on physical features and usability of the product while the second attends to issues of good experience and pleasure.

Aesthetic studies, however, are transversal and sometimes arising merely as a hedonic selling point that arouses the attention and desire of the client through a visual satisfaction (for example, Nenkov \& Scott, 2014) or debunking in utilitarian functions to increase the perceived value (as, for example, in Townsend \& Sood, 2012). As such, this theoretical essay seeks to shed new light on understanding the role of aesthetic products, but for this it is necessary to seek innovative reasons to justify a debate on a topic so consecrated as this.

Rather than seeking phenomenological or factual nuances that can contribute to scientific theory building, we chose to test this by entering the knowledge base that underlies such understandings and from a new construction to propose a theoretical contribution to the field. Thus, the purpose of this article is complemented by including the perspective of the philosophy of Schopenhauer (2012) to the understanding of the role of aesthetics in the purchase decision process.

The basis of knowledge that sustain the theory of consumer behavior are of Kantian origin and relate the phenomenon as the unit of analysis, quickly understanding hedonism and utilitarianism as essentially different times which ultimately are of distinct pragmatics to the purchasing process. However, this is not the only form of understanding possible.

For Schopenhauer (2012), beyond the phenomena exists a transcendental essence that makes up the universe and interferes with the lives of people. The metaphysics of beauty is trimming the schopenhauernian thought which interprets the relationship of people with symbols and art, interface that will be used in the construction of this theoretical essay. 
Thus, discussions of such depth require prior understanding of the structures that will be reinforced or reformulated. In order to engage in a constructive debate on the theory of consumer behavior, this theoretical essay will first revisit the scientific rhetoric and its analytic logic, the role of non-humans in the construction and legitimation of truth and theories, the whys of science that assume the fundamentalization of Marketing, the contemporary context in which the phenomena in question are occurring and finally a presentation of the understanding of the Schopenhauer philosophy (2012) and its use for the interpretation of aesthetics, hedonism and utilitarianism in Marketing.

\section{Scientific Rhetoric}

Scientific mechanisms have not always been present in human history. Such construction is the result of a favorable scenario that lasted for 300 years in Europe and is known as the Modern Age.

After the fall of the Western Roman Empire, Europe entered a period known as the Middle Ages, characterized by insecurity, disputed territories, the black plague and the lack of strong states. During the so-called Dark Ages, modern scientific mechanisms had not yet existed, and knowledge was managed in other ways, particularly in the Churches and supported in their holy books (Backman, 2008).

The situation in Medieval Europe, however, had changed significantly in the fifteenth century and in 1453, with the taking of Constantinople by the Ottoman Turks. With this marks the end of that era and the beginning of the Modern Age. This new timeline was marked by the rebirth of Europe through major achievements, such as transoceanic navigation, relative stabilization of territories through monarchies and the construction of science foundations by modern thinkers (Duiker, 2009).

Soon after, in his laboratory, Galilei (2014) began the most successful legitimation of non-human power of the last millennium. In its time, in the sixteenth century, the idea of heliocentrism was common, however the lack of legitimation overshadowed such stream of thought to the detriment of the indisputable metaphysical power of the Medieval Church.

In this context, there were the first experiments of Galilei (2014), which are particularly convincing when, for example, contradict the logic of falling bodies and demonstrate that large and small bodies fall at the same speed and time.

The observations of Galilei (2014), become indisputable then, and, conventionally baptized him as the inventor of experimental research. As such, the construction of one of the pillars of the modern and post-modern world is attributed to him. From the first experiments disguising themselves as science, power is silently transferred from human to non-human. The strength of the Galilei method (2014) is to elect a judge constantly and purposely confronted by the researcher, to resist proven theories while remaining impartial and unwavering.

Experimental research, such as medieval theology, must assume the basic precepts exempt of human interference, though this time they must also be replicable and refutable. As soon as the two bodies drop in free fall, Galilei (2014) does not interfere with the speed of the fall. He thoroughly explains his experiment so that anyone can later replicate it and get the same result (or contest it), and, finally, his test is designed so that the answer is impossible to know before performing it.

In this way, the writings of Galilei (2014), Descartes (2011), Hume (2014), Bacon (2008), Newton (2013), and others, have promoted a silent intellectual revolution that, in the end, overcame even the classic writings of Socrates, Plato and Aristotle. Although scattered and not as deliberate as the Greeks, European thinkers have developed understandings about the ways of obtaining knowledge we now call modern science, or simply science.

Although developed in the modern age, our notion of science was only conceived in the late eighteenth century, when Kant (2013) suggested that timely metaphysics and epistemology were different doctrines and should be understood in isolation. Not so coincidentally, this was the same period that Europe experienced the French Revolution, the fall of the absolutist regimes, the rise of the bourgeoisie, the weakening of religion and the need for people to seek a legitimizing organ independent of state and religion.

Thus, in 1789 the Modern Age comes to an end and leaves science as its greatest legacy to contemporary civilization. Scientific mechanisms are impartial, controlled by non-humans, meritocrats and perfectly meet the need of post-revolution. The great impartial judge of Nature takes control of knowledge, and in this respect is independent and superior to the State and the Church.

Collaterally to this policy choice by modern science as universal knowledge manager, man saw an unprecedented technological revolution. In the late nineteenth century, Diesel discovered the internal combustion 
engine (Rajeesh, Prakash, \& Kulkarni, 2014), and in 1969 the world watched Armstrong, on television, utter his famous words 350,000 kilometers away from Houston. In other more impactful words, mankind literally got off the saddle to walk on the moon in approximately 100 years, and such a fact crowned science as undisputed knowledge manager, not only in technology, but in social doctrines such as administration, marketing and consumer behavior.

The world suffered another drastic change in their socio-economic-political-scientific configuration around 1989. The fall of the Berlin wall marked the end of the continental wars, apogee of capitalism, the rise of democracy as the only legitimate form of government and crisis in modern science.

After the consolidation of capitalism in the 1990s as a global economic system, studies in the field of consumer behavior experienced a vertical growth in number of journals, authors, educational and research institutions and private investment. One of the effects of globalization has been the increased competition over national boundaries which forced scholars of consumer behavior to understand quickly and efficiently the mechanisms that could make companies gain more markets, such was the success of the scientific method in the hard sciences, which ended up also adopting these precepts in this expansion.

The post-war world, shaken military advances packaged by the teachings of Kant, Newton, Galileo and Einstein, then, questioned the hegemony of this method and all the power it conferred. Science, as the dominant paradigm is, then, the target of all forms of critics.

The judge figure, which is neither human and nor metaphysical (Kant, 2013), was first intended to transfer knowledge of cloistered institutions to the general public in a democratic movement. As such, anyone could produce knowledge, provided that appropriate methods are used for this purpose.

Democratization, however, is strongly shaken by the arguments of Lyotard (1984), who in his first revision builds a clear rationale which shows that scientific progress is dangerously bolstered in non-human technological possibilities of the development of judges.

All were impressed with the discovery of Higgs (2010), but few paid attention to the fact that this knowledge was only possible at the cost of approximately 7.5 billion euros (CERN, 2010) that was spent to build the most complex science we have today, including a particle accelerator between France and Switzerland.

Lyotard (1984) seems, then, successful in his interpretation of reality. Producing knowledge under the tools costing billions of euros is not full democracy, and although the ideas of Galilei (2014) have been preserved, non-humans are expensive and too inaccessible, such as the holy book that he even helped to disempower.

The flirtation between capital and knowledge is, therefore, one of the criticisms of modern science. CERN in physics, ISS in astronomy, territorial censuses in applied social sciences and pharmacology in the laboratory industry are examples of knowledge produced under the restricted possibilities of capital.

The influence, then, of capital, for Lyotard (1984), in knowledge production ranges from, at minimum, more attention to the research fields that give more profit up to, at most, a deliberate manipulation of results. The irreplicability afforded by the billion dollar research flees to the spirit of democratization of Galilei (2014). Yet in this perspective, having or not having money is not a characteristic provided by Kant (2013) and represents an anomoly of the modern scientific production process. But all this happens while the large investment funds on research argue about the benefit of capital on the performance of scientific results.

There is no doubt that the world-class corporations have more resources to develop research on consumer behavior and in their own way create an advantage over competitors, with knowledge no longer democratic.

In a way, the influence of capital on the possibilities of non-human judges is, ultimately, the very human influence on the research instrument and, therefore, we are led to the hybrid bodies of Latour (1993), where scientist and instrument become one, and not two as Galilei wanted (2014). The problem, however, of this configuration, for Latour (1993), is that awareness about hybrids impedes us (and will always impede us) from being modern, like Kant (2013) wanted or how Galilei (2014) suggested. To not be modern in no way affects the pragmatic performance of scientific discoveries, but it does affect legitimate power. Fertile ground for post-modern propositions terrain. If Latour (1993) was able to observe influence on non-human actors in airtight laboratory environments, the extent of this understanding for social sciences tends to be catastrophic.

\section{The Role of Non-Humans}

Living in Europe during the Middle Ages must not have been easy, the fall of the Western Roman Empire discharged the tribes living under the law of Rome, and, somehow, allowed each small group to have its own laws. Without a general command, the meeting between tribes was completely unregulated with looting and 
banalized murder. This chaotic environment was the basis of the thoughts of Hobbes (2013), which resulted in one of the most striking reflections inthe history of society.

In Leviathan, Hobbes (2013), influenced by what he heard about the barbarism of the Middle Ages, suggests a typically modern solution of the non-human judge. Just as Galilei (2014), who exempts the conclusions and cultured instruments by their findings, Hobbes (2013) states that man is more selfish than previously thought and, thus, should be controlled by something.

The figure of a superior human with powers to govern the state is as old as human history itself, but for the first time a chain of thoughts took force trying to legitimize that someone could possess power without any appeal to metaphysics. Thus, prior to Kant and the Jacobins, Hobbes (2013) dissected the metaphysics and began to seek unquestioned elements that could legitimize power.

Without a theology that would provide unlimited power to the sovereign, who would be human and become a superhuman, Hobbes (2013) suggests making a kind ofdocument called Social Contract. In this way, surreptitiously and without fanfare, the power of knowledge is no longer the ruler and becomes a non-human actor (although that built by humans, like a telescope). Thus, Hobbes (2013) alleviates the figure of a sovereign and categorically states that, regardless of who occupies this position, he will bow to the Moral and Justice ultimately configured on a Social Contract.

The vectors of Newton (2013) are the Social Contract of Hobbes (2013). More by personal interests than that of physical, they are inevitably tied to the cold reality of natural laws, their algorithms and philosophy mathematical. Equally domesticated will be sovereigns that are everywhere defined by the Social Contract. With this slight shift, society would no longer bow to an individual but, rather, to a non-human figure. Reinforcing the premises of Hobbes (2013), our egoism is satisfied to learn that even the ruler could not govern their own free will, but only manifest an impersonal and inflexible code.

Perhaps the same reasons that led Hobbes (2013) to paternalism of Justice aroused the spirit of modern ideas. Modern science has emptied the power of the Medieval Church and determined that knowledge would no longer be the fruit of holy books, but rather from logical constructions by instrumentation and non-human arbiters. Such context led Nietzsche (2013) to utter the most famous of his sayings "Gott ist tot".

Anyone who might be Sovereign understands that the real ruler is the Social Contract, just as anyone who might produce knowledge will obey the scientific method. Finally, the Greek democratic ideas received the additive that allowed its implementation on a global scale. The ideals of equality and freedom represent this new form of science that ensures opportunities to all men without hurting their ego with obedience to others.

The presence of non-humans in consumer behavior research is essential for the academia and the market to believe in the exemption of results. In this way, the use of questionnaires and statistical analysis attribute particular value to market research, especially in consultancies. In the contact between theory and practice, it was conventional to build knowledge in scientific rhetoric making use of non-humans and exercising to exhaustion the principle of replicability. The original studies of Kotler (1973), for example, are perhaps the most replicated in the history of Marketing infinitely investigating what the actual effect is on the retail consumer behavior environment.

Another non-human success of marketing (similar to consumer behavior, but with great interface) is the SERVQUAL scale, which is perhaps one of the instruments most tested, criticized, replicated and used in services marketing (for example, Sivakumar, Mei, \& Beibei, 2014). The market and academia yield to the result of a SERVQUAL test with subservience never shown to any other human thinking in Marketing. We are modern, however much Latour (1993) insists that no (provocative statement).

Even to the point of concluding that the legitimation of power was the crucial factor to for the rise of modern science, this quality itself is not sustainable unless the mechanisms of knowledge production function.

\section{The Whys of Science}

The basis of scientific constructs is the Kantian understanding that there is a clear separation between Nature and Society. The human egocentrism spiked by Hobbes (2013) impedes the understanding that human actions are not deliberate, but empiricism shows us that we are surrounded by phenomena which we do not control and do not even understand. In this context, Nature emerges as a universal explanation for everything that happens and that has not been created by man.

On the path of Natural understanding arises the important figure of Descartes (2011) which, supported by Euclid (Heath, 2010), spread the idea that knowledge is axiomatic, for example, when faced with a complex 
phenomenon it is necessary to thresh and understand it in its smallest components, propagating, then, to reductionism.

The axiomatic conception is observed in almost all theories of consumer behavior, as in the purchase decision-making process (for example, Sevilla \& Kahn, 2014) which drafted in Euclidean metaphor to understand that the process itself is the plan, composed of steps (straight), subdivided into dimensions (points) that must be understood and explained individually so that the theory as a whole is revealed.

With this new Cartesian configuration of Nature, man will always be faced with phenomena small enough to be properly investigated, such as the effect of the product position in the gondola (Dagger \& Danaher, 2014), or ambient music (Simões \& Agante, 2014), or POS illumination (Challagalla, Murtha, \& Jaworski, 2014) in understanding the phenomenon of consumer behavior (incomprehensible for a single outlet). From this perspective, science is configured primarily as an entity created from the union of the axiomatic understanding of Descartes (2011), experimental techniques Galilei (2014) and neutrality of a non-human Judge of Hobbes (2013).

Henceforth other ontologies will quantitate how much of Nature and how much Society each will add to its current understanding of things (Latour, 1993), none of which actually breaks with this dogmatic idea, contrary to what Lyotard preached (1984).

One can criticize the impartiality of the instruments of Galileo is not true and that the pretense of studying Nature without disturbing it itself is only a pretense. Some have said that the Social component is so present that each phenomenon is unique and unrepeatable, but all agree that to some degree there is a duality.

To distance himself from Nature permits man to feel no pain while exploring what is not human. To assume that is no right answer and to find it is a matter of time (and maybe time is never enough), exempt us from the guilt and pain of ignorance. However, the link that connects the modern world of contemporary science is so fragile as Lyotard (1984) makes it seem, so complex as Habermas (1976) wanted and so logical when Wittgenstein (2001) is able to describe it. A propitious moment to enter the scientific crisis which afforded the first post-modern movements.

Non-humans do not feel the pain that a consumer can feel when struck by the theories of consumption and the scientist is absolved of blame, after all it is not the judge of reason. Is there a crime if there is no one to blame?

\section{Contemporary Context}

The configuration of the post-modern scenario relies on arguments of different intensities, among which highlights the issue of the legitimation of power and the value of information (and its source) as a basic propositional component of knowledge.

Initially, as a way of exalting the importance of information in the context of knowledge generation, it is emphasized that the scientific issues can be understood by the study of logic, like Russell (2013), Getter (2012) and Wittgenstein I (1998), where propositions represent the basic component and the indissoluble formulation of knowledge, and, under certain rule, they should be contrasted and confronted in order to produce truths.

Still under the school of Kant (2013) and subsequently endorsed by Popper (2002), the propositions must be composed of elements that to some degree are connected to private aspects, delimited and very well defined in the factual world. Such statements, when organized according to logic, are capable, then, to be justified. Therefore, the proposals go from being inferences to becoming truths.

Contemporaneously, such semantic functions no longer represent the strongest component of the words, as Wittgenstein II asserts (2001), as these carry a meaning and a pragmatic objective that can not be revealed in a decontextualized way. Which largely aroused the interest of Lyotard (1984), the most notable of post-modern thinkers, as it will be elucidated later.

Accordingly, in the post-modern world, access to knowledge and information are overestimated and should become the target of governments more ambitious than they once were th the past with territories and natural resources. Lyotard (1984) mentions this, including the possibility of military confrontations by information and fear of terror control, in the event knowledge is locked within the privileged few.

In the construction of this same scenario, it has already provided the technological and telecommunications revolution. Information, then, in post-modern times assumes its own way, completely free of scientific narrative. Namely, any statement should be considered a form of knowledge, whether or not this subordinates the dominant methodologies. A disruption not with Popper (2002), but, with modern science as the only valid unit of knowledge production. 
Impressive is the capacity of Lyotard (1984) to describe the movements in computer mediated social networks long before the web became a viable possibility. An illustrative parallel can be made to statements that are published on the internet by users and are taken as truths by the community. Step by step, society begins to build knowledge based on personal opinions, inferences and other non-scientific sources.

The assays Lyotard (1984) and his commentators shake, then, the legitimate power of modern science, demystifying non-human forms of judgment and debasing scientific knowledge to a propositional level, or in other words equating it with too many inferences, of which all information is now called.

If the original order was restricting the wording and interpretation of the elected Social Contract then, nowadays, any individual with high communication skills can reinterpret the texts and produce a social truth. Thus, ordinary people construct a collective knowledge of which particular political party is corrupt, so such a law has a loophole or else any new jurisdiction will certainly benefit some dishonest businessman. Flawless reasoning, whereas society is dynamic and always will respond to the situation with involuntary movements of reaction, similar to the economic proposition of Smith (2014) in kinetics. Movements, which, in my view, have already begun and slightly contradict the predictions of Lyotard (1984).

Information is really abundant, and due to the telecommunications revolution, the optimistic scenario of Lyotard (1984) became a reality because everyone has access to much more information than they want or are able to process. Secrets of states and scientific discoveries of the last hour are accessible by ordinary people anywhere in the world in near real time.

In contrast, the accused defend themselves. After all, the information is free and its channels accessible. Thus, the corrupt party can declare themselves persecuted, laws can be reinterpreted by the press that convinces us massively that such a gap never existed or entrepreneurs can demonstrate that private initiatives are more agile and efficient than public ones, and that they actually are the saviors, not the executioners, of society.

However, contrary to what one might assume, the narratives goals were not met, leaving an intermittent vacancy that may be filled again at any time. Then, in the middle of the informational war people just have to make a sensible resource: create their own mechanisms of judgment between what is true and what is not.

If we bring in Wittgenstein II (2001) for this debate we will observe that sentences derived from social networks have only a semantic sense devoid of context (the external) and therefore the pragmatics of language became indecipherable. Thus, companies seeking fragments about their brands on social networks, for example, never attain the objective of communication which they face, with everything becoming mere objectification of the researcher, that with some or no pudency can conclude under their own logic anything they want. Logic similar to the laboratories Latour (1993), but with less refined instrumentarium and, therefore, less non-human.

Decisions made under knowledge created in this manner can not somehow lead us to another scenario that is not the liquid modernity of Bauman (2000). Our awareness of the inability to understand and predict events become interim decisions, while indisputable truths serve the micro-temporal context in which it is supposed to work.

But, just like the definitions of liquid modernity of Bauman (2000), postmodern information was also not built to last. The condition of Lyotard (1984) did not foresee that, while information emerged and suffered with much greater speed in the modern period, and without scientific narrative, this movement not only gains speed but also grows amazingly in scale. Currently, anyone using a web connection can produce information that, if followed and shared by other users, will traverse the network in a few seconds, gain relevance, taking contours of liquid knowledge and, at the same speed, fall in oblivion.

Creating ones own mechanisms of judgment and justification does not fully address the problem, first because we are social beings and secondly becauseit takes much work to communicate in a world where each one has his own criteria of truth and, finally, because Wittgenstein II (2001) teaches us that semantics is not essential. Naturally the criteria will converge around a new (but not necessarily innovative) paradigm. In accordance, people notice that information is not secure and that knowledge based on them is always temporary and increasingly in shorter cycles, the next move, I believe, will be the search for consensual legitimacy. The knowledge will again leisurely seek a safe haven to brake the speed of information and make people take time to appreciate the balance.

Is it not strange to see people return to the official communication channels, such as the press, when want to make sure if the news they have access to by social media is actually true. Likewise, it would not be utopian to imagine that people would again seek a reference of knowledge in encyclopedias and a definitive explanation in legal codes for what may or may not be.

The large negatives have already demonstrated a consensual Will to curb the postmodern informational process: 
the decadency of the fast-food model, the negation of fast cars in favor of slow bikes, the labor unions seeking a reduction in working hours, the French, particularly, by repudiating professional emails outside of work hours and ultimately a counter-cultural disconnect from the web and exploring personal relationships.

The reduction of information, a decisive factor for slowing the rhythm of life is likely to adopt a consensual criteria, a narrative goal, that nurtures people into feeling that they are not losing quantities of information, but instead are gaining quality.

Thus, the current context calls for debate the philosophy of Schopenhauer (2012) based on a reinterpretation of the Kantian modernity, however using the metaphysics of Will as a valid explanation for contemporary life and our perception (Representation/Idea) about it.

Schopenhauer (2012) unlike Wittgenstein II (2001) does not seek the origin of knowledge in language, and in opposition to Lyotard (1984) does not believe that all information is external and thus a technological revolution could change the essence of being human. It would make little or no sense to frame the non-humans of Latour (1993) in a Schopenhauerniana perspective, being that they are just as Will regarding us and to some degree the whole scientific judgment is a great Representation (Idea) in a pure phenomenological sense of the Kantian critique.

Subjugated to postmodern scientific debate, Schopenhauer (2012) is one of the most influential thinkers in recent history, they are his inspirations that allow academic studies in various fields, especially marketing, even if theoretical essays rarely resume the origin of thought on which they are leaning. Bringing to light the Schopenhauerian doctrine is a way to explain how the origin of hedonic Marketing meets the postmodern context and, therefore, orders a debate which does not fit in itself. It is, at the end of everything, to understand man, his essence and movements that will guide our lifestyle in the coming decades.

\section{The Comprehension of Schopenhauer}

The work 'The World as Will and Representation (Idea)' is a powerful philosophical essay on the essence of man and the origin of his knowledge. In his four volumes, Schopenhauer (2012) exposes his thoughts about how science building would have been lost after the Kantian division and the implications for our self understanding.

An enjoyable and deep reading, 'The World as Will and Representation (Idea)' is a dense essay that requires a number of assumptions from the reader, like understandings about the Kantian, Scholastic and Classical doctrine. Schopenhauer (2012) constantly refers to these schools in order to boost his own philosophy and with this the writings are a profound revision of the history of human knowledge so far. The melancholy personality of Schopenhauer (2012) gives a pessimistic tone of his writings and through such darkness it is possible to see the metaphysical essays on happiness at the end of the third volume.

(...) who would go on living life as it is, if death were less terrible?-And who could even so much as endure the thought of death, if life were a joy? And who could bear even the mere thought of death if life were a pleasure? But the former still always has the good point of being the end of life and we console ourselves with death in regard to the sufferings of life, and with the sufferings of life in regard to death. The truth is that the two belong to each other inseparably, since they constitute a deviation from the right path, and a return to this is as difficult as it is desirable. (Schopenhauer, 1883, p. 677)

In the first volume we are introduced to the concept of Representation (Will) where Schopenhauer (2012) presents the world as a mere Representation of things in themselves, something not accessible by pure knowledge of reason. The narrative at this point, while rousing, approaches the phenomenological view of Kant (2013). In these early passages, Schopenhauer (2012) leads us to believe that the representation is not satisfactory to complete knowledge about things, even if such are reduced to phenomenon.

In endless space countless luminous spheres, round each of which some dozen smaller illuminated ones revolve, hot at the core and covered over with a hard cold crust; on this crust a mouldy film has produced living and knowing beings: this is empirical truth, the real, the world. (Schopenhauer, 1883, p. 194)

Representation, as a pure form of reason and worldly understanding exempts metaphysics and also relies on British empiricist school (for example, Bacon, 2008; Hume, 2014) where our senses are responsible for capturing the phenomenological manifestations that are judged by reason. Although the thing itself is never denied, it is understood that our knowledge is forced into empiricism.

The rupture of the Schopenhauerniana philosophy occurs by Kant (2013) suggesting that people are endowed with two sources of knowledge, the ability to receive representations and also knowing an object through these representations. While it is possible through the first sense and remains unchanged in 'The World as Will and 
Representation (Idea)', the second requires, according to Schopenhauer (2012), a dose of intuition and a priori knowledge, because he believes that it must be necessary for something to previously exist for the subject and object to exist and, logically, something unconscious must be anticipated in our judgment so that there is the very mechanisms of conscious knowledge.

(...) that what is called in the Kantian philosophy the thing-in-itself, and appears there as so significant, and yet so obscure and paradoxical a doctrine, and especially on account of the manner in which Kant introduced it as an inference from the caused to the cause, was considered a stumbling-stone, and, in fact, the weak side of his philosophy, - that this, I say, if it is reached by the entirely different way by which we have arrived at it, is nothing but the Will when the sphere of that conception is extended and defined in the way I have shown. I hope, further, that after what has been said there will be no hesitation in recognising the definite grades of the objectification of the will, which is the inner reality of the world, (Schoupenhauer, 1883, p. 3)

Although the Kantian logic is widely accepted and the technological representations are their safe haven in academic discussions, the Schopenhauerian argument is equally high and makes us believe with property that the object and the subject not existing prior to the phenomenology phenomenon is an empty doctrine, and if there already is, in fact, an unconscious way until becoming conscience, reason and finally phenomenon.

What would be formed, then, with respect to unconscious Nature? By its own limitations that Wittgenstein II (2001) elucidates so well in Philosophical Investigations, Schopenhauer (2012) can not aim for metaphysics language of things in themselves, and to refer to them, uses the word Will.

(...) Will, which proved to be simply what this world is besides being representation. In accordance with this knowledge, we called the world as representation, both as a whole and in its parts, the objectivity of the will, which accordingly means the will become object, i.e., representation. Now we recall further that such objectification of the will had many but definite grades, at which, with gradually increasing distinctness and completeness, the inner nature of the will appeared in the representation, in other words, presented itself as object. (Schopenhauer, 1883, p. 1).

Will, though unconscious, is present in us and in the things of Nature and can be felt, not by sensory organs, but by intuition and sensitivity of the soul. If phenomena are punctual and limited in all its conceptions, Will is eternal and therefore becomes more influential in our day-to-day than any Kantian science could be.

The essential in all these grades of the will's objectification constitutes the Idea; on the other hand, its unfolding or development, because drawn apart in the forms of the principle of sufficient reason into a multiplicity of many-sided phenomena, is inessential to the Idea; it lies merely in the individual's mode of cognition, and has reality only for that individual. Now the same thing necessarily holds good of the unfolding of that Idea which is the most complete objectivity of the will. Consequently, the history of the human race, the throng of events, the change of times, the many varying forms of human life in different countries and centuries, all this is only the accidental form of the phenomenon of the Idea. All this does not belong to the Idea itself, in which alone lies the adequate objectivity of the will, but only to the phenomenon. The phenomenon comes into the knowledge of the individual, and is just as foreign, inessential, and indifferent to the Idea itself as the figures they depict are to the clouds, the shape of its eddies and foam-forms to the brook, and the trees and flowers to the ice. (Schopenhauer, 1883, p. 15)

Will that composes men, for Schopenhauer (2012), is essentially pain. It was he who said that we are not able to feel health more than the pain, that the entire body can be healthier than the pain of an ingrown toenail protruding in our perception. Speaking about passages of everyday life, Schopenhauer (2012) attributes the pain to our foray against the objectives we want to achieve and the arduous journey that is done to them, and also pain to the achievement of these, after all the feeling that there is nothingo more to do leads to boredom, anxiety and depression.

Unlike animals not endowed with Representation (Idea), we were unable for a single moment to feel the satisfaction and eternal pleasure by just existing, something more is always needed to escape the pain that shape our Will and ourselves.

Among the various reflections of 'The World as Will and Representation (Idea)', Schopenhauer (2012) presents his important understanding of time and space as a function of the human condition for development of the phenomenological concept. understanding by the research question of this theoretical essay.

In simplistic and deliberately insinuating rationale, it can expressed that time is a social product and, therefore, not Natural. Our understanding of causality is given due to the perception that things happen sequentially, and thus the concept of time is essential to understanding the phenomena and delineation of causal relationships. 
All relation has itself only a relative existence; for example, all being in time is also a non-being, for time is just that by which opposite determinations can belong to the same thing. Therefore every phenomenon in time again is not, for what separates its beginning from its end is simply time, essentially an evanescent, unstable, and relative thing, here called duration. (Schopenhauer, 1883, p. 10).

For Schopenhauer (2012) there is no experimentation that proves the existence of time (Kantian fallacy, and why not Popperian?), time is not experienced by the senses and also has no essence (Will) as things in themselves. To temporize, therefore, is the only reasonable explanation that reason orders us to understand that it takes something, or, something is brought.

With time being an oppressor of Representation (idea) related to our pessimistic essence, there seems to be no solution for man, and in fact there is no way that metaphysics of beauty can be understood. Schopenhauer (2012) argues that our Will should not be controlled by representations (idea), but rather by aesthetics, a solution and metaphysical encounter. Rhetoric over time is a remarkable argument on the work of Schopenhauer (2012), however this essay will focus on the root of pessimism and its alternatives, moreso in Will (Will) than Representation (Idea).

Although sensible and convincing in pessimistic rhetoric, Schopenhauer (2012) suggests that Will, our essence formed from pain and tedium, is relieved to encounter the arts, a direct portal between the senses and metaphysics. Although they belong to the Representation (idea), the art pieces can go through our senses and communicate with the soul without the use of language and awakening unspeakable sensations

I return to our discussion of the aesthetic impression. Knowledge of the beautiful always supposes, simultaneously and inseparably, a purely knowing subject and a known Idea as object. But yet the source of aesthetic enjoyment will lie sometimes rather in the apprehension of the known Idea, sometimes rather in the bliss and peace of mind of pure knowledge free from all willing, and thus from all individuality and the pain that results therefrom. And in fact, this predominance of the one or the other constituent element of aesthetic enjoyment will depend on whether the intuitively grasped Idea is a higher or a lower grade of the will's objectivity. (Schopenhauer, 2012, p. 244)

Among the clues that the philosopher provides to find our peace is aesthetics, which awaken our tranquility by communicating directly with Will, without the need to interpret it. Of which the most striking example is the instant relief that a song can bring us, without us knowing how to explain explain or even comprehend why.

Human beauty is an objective expression that denotes the will's most complete objectification at 'the highest grade at which this is knowable, namely the Idea of man in general, completely and fully expressed in the perceived form. But however much the objective side of the beautiful appears here, the subjective still always remains its constant companion. No object transports us so rapidly into purely aesthetic contemplation as the most beautiful human countenance and form, at the sight of which we are instantly seized by an inexpressible satisfaction and lifted above ourselves and all that torments us. This is possible only because of the fact that this most distinct and purest perceptibility of the will raises us most easily and rapidly into the state of pure knowing in which our personality, our willing with its constant pain, disappears, as long as the purely aesthetic pleasure lasts (Schopenhauer, 2012, p. 52).

The interface which is proposed, then, with consumer behavior is precisely the escape of Representation (idea) and from time oppression, from the pain of Will and from our tragically melancholic end by aesthetics. However, as Schopenhauer (2012) points out, there is no aesthetic that leads to equilibrium, the suggestive and provocative arts are so painful to end as much as it tries to combat it, it is necessary to seek art in the improbable.

A brief distinction of the terms a priori, sublime and provocative should be made. While the first accesses the peace of soul and balances the subject through contemplation of the essence of things in expected metaphysics, the second is the mere attraction of Representation which, at the end of it all, brings back the original pain that Schopenhauer (2012) warns us about. As much as sublime citations speak of aesthetic and contemplation, when referring to the provocative is pure symbolism.

\section{Aesthetics, Hedonism and Utilitarianism in Marketing}

The brevity of the liquid forms contextualized by Bauman (2000) makes us understand that the consumer may assume a role much less utilitarian than it appears, as there is some confusion between happiness and peace of mind or fulfilling immediate goals, which are to aquire products. The set of acts that form the consumption phenomenon are beyond the pragmatics of purchase, and are for a happier life.

Utilitarian and hedonic purchases have been a widely discussed theme by Marketing academia for some time (for example, Doong et al., 2012) but not from the perspective of Bauman's liquid modernity (2000) nor 
Schopenhauer's metaphysics of beauty (2012).

Utilitarian consumption is regarded as an action of little aesthetic dependency even in classical literature, where the predominant physical characteristics and consumer information are not flawed by coolness and objectivity (Doong et al., 2012). Experiencing such a consumption experience is to assume the Representation (Idea) of Schopenhauer (2012) as a satisfactory interface between the person and nature. The product assumes its physical, human characteristic and with immediate practical purpose, disposable, while the problem to be fixed feature no longer exists.

People may seem utilitarian and adhere to this form of consumption realizing that something that bothers them can be remedied immediately through some acquisition. Such action is absolutely reprehensible, we are all like this, though the categorical Schopenhauerian philosophy is to equate such problems to our painful Will which brings any discontent to the fore to the detriment of all the peace that could simultaneously encircle us. To buy is to cherish the pain, and the pain not to have more trouble to be cherished. A vicious circle between solving a problem and seeking another to be solved, is that there will always be a problem and, if this is not the Will, then it shall make its melancholic role.

While it is hedonic consumption, pragmatically it does not represent a true solution in the perspective of Schopenhauer (2012). It is defined as something that satisfies people internally beyond functional criteria and awakens pleasurable experiences in us consumers (Salerno, Laran, \& Janiszewski, 2014). However, such satiety is also immediate and particularly linked to the phenomenon of consumption thus maintaining their next utilitarianism bases, objectifying solution for sentimental rather than technical problems, hedonic consumption does not achieve the righteousness of the metaphysics of beauty, not properly balancing Will and leads people (more smoothly) to the same vicious circle of melancholy, dosing homeopathic happiness to each new purchase, but never permanently.

The direction Marketing academia took demonstrates that efforts to understand the world are based on Representation (Idea), obviously remnants of Kantanian thought and its disciples, and which, according to Schopenhauer (2012), is precisely why it induces a melancholic end. Examples of these studies are investigations that provide companies' understandings of how children can influence the buying decision of parents (Ülger \& Ülger, 2012) or the reason people spend more than planned (Sussman \& Alter, 2012).

At the contemporary marketing school itself, however, there are clues that would lead us to solutions proposed by the metaphysics of beauty, such as aesthetics. For Schopenhauer (2012), the balance of man is reached when he enters the universe of aesthetic arts and ridding himself of language and pure reason rnchants him with the sublime and soothes the painful understanding of Will.

Just as Townsend and Sood (2012) suggest, well crafted aesthetic products sell more, are perceived as more valuable and more pleasing to consumers. Townsend and Sood (2012) sought purely rational explanations (immanent) for the finding of their research, but Schopenhauer (2012) would indicate a transcendental position to be found.

Complementarily, Schopenhauer (2012) also would caution Townsend and Sood (2012) that the aesthetic value is perceived as very valuable and perennial as much as the provocative escape. The metaphysics of beauty discard that equilibrium can be achieved by symbols, alerting especially the sensual and erotic, which would be just another Representation (Idea) such as utilitarian or hedonic such as the propositions of Doong et al. (2012) that were not cherished for more than an instant.

Therefore, this contemporary movement in search of better quality of life, Marketing must have noted its contribution positively by society. It is believed that to understand Schopenhauerian doctrine is an important step towards providing consumers with more than immediate relief, after all the art that may be provided by the aesthetic is as perennial as much as the duration of the product in the lives of people. In this sense, Nenkov and Scott (2014) also demonstrated such concern and admitted that visual communication of aesthetic appeal has greater commercial appeal, but this time, according to Schopenhauer (2012), the marketing objectives and the avoidance of pain converge to nearby targets.

\section{Final Considerations}

The philosophy of Schopenhauer (2012) is marked by Kantian antagonism and in alignment with Nietzsche (2013). One of the last thinkers to consider the metaphysical as a valid explanation for the original philosophical questions, Schopenhauer (2012) is respected for his outstanding contribution to the reflection of man and his constant struggle against even himself.

Just as the principal names of his time, the contribution of Schopenhauer (2012) is perennial and independent of 
the direction that contemporary philosophical debate takes. In this sense, the purpose of this theoretical essay was to redeem the metaphysics of beauty considered one of the key milestones in ones thinking to better understand current consumer issues and preference to aesthetically pleasing.

Understanding the aesthetic role of the product itself is circular and returns in different ways the raw physics of functionalism or utility consumption, in opposition then to this line of reasoning, which has been discussed in this work that the artistic issues are of higher order and communicated (they are perceived, experienced) in a particular way by people.

To surrender to beauty is the transcendental function that brings peace and balance to the Natural pessimism of people, thus Marketing must occupy this task of collaborating with the escape from the pain of Will. The solution, then, that unites Schopenhauerian thinking and the marketing objectives of Marketing is seeking a design based on the aesthetics of the sublime.

\section{References}

Backman, C. R. (2008). The worlds of medieval Europe. Oxford, UK: Oxford University Press.

Bacon, F. (2008). The major works (Oxford world's classics). New York: Oxford University Press.

Bauman, Z. (2000). Liquid modernity. Cambridge: Polity.

CERN. (2010). CERN - the large hadron collider.

Challagalla, G., Murtha, B. R., \& Jaworski, B. (2014). Marketing doctrine: A principles- based approach to guiding marketing decision making in firms. Journal of Marketing, 784-820. http://dx.doi.org/10.1509/jm.12.0314

Dagger, T. S., \& Danaher, P. J. (2014). Comparing the effect of store remodeling on new and existing customers. Journal of Marketing, 78(3), 62-80. http://dx.doi.org/10.1509/jm.13.0272

Descartes, R. (2011). Discourse on the method and meditations on first philosophy. Indianapolis: Create Space Independent Publishing Platform.

Doong, H., Wang, H., \& Law, R. (2012). An examination of the determinants of in-flight duty-free shopping: Hedonic and utilitarian motivations. International Journal of Tourism Research, 14(3), 303-306. http://dx.doi.org/10.1002/jtr.1870

Duiker, W. J. (2009). Contemporary history of the world. New York: Cengage Learning.

Eric, W. R. (2003). Ancient greek democracy: Readings and sources. John Wiley and Sons Ltd.

Galilei, G. (2014). Dialogues concerning two new sciences. New York: Literary Licensing, LLC.

Gettier, E. L. (2012). Is justified true belief knowledge? Princeton: Princeton University Press.

Habermas, J. (1976). Legitimarion crisis. London: Heinemann.

Heath, T. L. (2010). The thirteen books of euclid's elements. New York: Digireads.com.

Higgs, P. (2010). My life as a boson. Talk given at Kings College, London, Nov 242010.

Hobbes, T. (2013). Leviathan. New York: Renaissance Books.

Hume, D. (2014). An enquiry concerning human understanding. Oxford: Hume \& Doom.

James, W. (2013). Pragmatism. New York: CreateSpace Independent Publishing Platform.

Jean-François, L. (1984). The postmodern condition: A report on knowledge. Minneapolis: University of Minnesota Press.

Kant, I. (2013). The critique of pure reason. New York: CreateSpace Independent Publishing Platform.

Kotler, P. (1973). Atmospherics as a marketing tool. Journal of Retailing, 49(4), 48-64.

Latour, B. (1993). We have never been modern. Boston: Harvard University Press.

Nenkov, G. Y., \& Scott, M. L. (2014). "So cute i could eat it up": Priming effects of cute products on indulgent consumption. Journal of Consumer Research, 41(2), 326-341. http://dx.doi.org/10.1086/676581

Newton, I. (2013). The principia: Mathematical principles of natural philosophy. New York: CreateSpace Independent Publishing Platform.

Nietzsche, F. (2013). The anti-christ. New York: SoHo Books.

Popper, K. R. (2002). The logic of scientific discovery. New York: Routledge. 
Rajeesh, S., Prakash, S. V., \& Kulkarni, G. V. (2014). Performance analysis of diesel engine using Cashew Nut Shell Liquid (CNSL) biodiesel and Cashew Nut Shell Liquid (CNSL) blended with ethanol as a alternative. Journal of Mechanical Engineering Research and Technology, 2(1), 546-554.

Russell, B. (2013). The problems of philosophy. London: Von Schtupp Press.

Salerno, A., Laran, J., \& Janiszewski, C. (2014). Hedonic eating goals and emotion: When sadness decreases the desire to indulge. Journal of Consumer Research, 41(1), 135-151. http://dx.doi.org/10.1086/675299

Schopenhauer, A. (2012). The world as will and idea. London: Digireads.com.

Sevilla, J., \& Kahn, B. E. (2014). The completeness heuristic: Product shape completeness influences size perceptions, preference, and consumption. Journal of Marketing Research (JMR), 51(1), 57-68. http://dx.doi.org/10.1509/jmr.12.0153

Simões, I., \& Agante, L. (2014). The impact of event sponsorship on Portuguese children's brand image and purchase intentions: The moderator effects of product involvement and brand familiarity. International Journal of Advertising, 33(3), 533-556. http://dx.doi.org/10.2501/IJA-33-3-533-556

Sivakumar, K. K., Mei, L., \& Beibei, D. (2014). Service quality: The impact of frequency, timing, proximity, and sequence of failures and delights. Journal of Marketing, 78(1), 41-58. http://dx.doi.org/10.1509/jm.12.0527

Smith, A. (2014). The wealth of nations. New York: CreateSpace Independent Publishing Platform.

Sussman, A. B., \& Alter, A. L. (2012). The exception is the rule: Underestimating and overspending on exceptional expenses. Journal of Consumer Research, 39(4), 800-814. http://dx.doi.org/10.1086/665833

Townsend, C., \& Sood, S. (2012). Self-affirmation through the choice of highly aesthetic products. Journal of Consumer Research, 39(2), 415-428. http://dx.doi.org/10.1086/663775

Ülger, G. G., \& Ülger, B. B. (2012). Children in family purchase decision-making: Children's role in food product purchases from mothers' point of view. Journal of Marketing Communications, 18(4), 297-320. http://dx.doi.org/10.1080/13527266.2010.528994

Wittgenstein, II, L. (2001). Philosophical investigations. London: Blackwell Publishing.

Wittgenstein, I. L. (1998). Tractatus logico-philosophicus. London: Dover Publications.

\section{Copyrights}

Copyright for this article is retained by the author(s), with first publication rights granted to the journal.

This is an open-access article distributed under the terms and conditions of the Creative Commons Attribution license (http://creativecommons.org/licenses/by/3.0/). 